\title{
Correction to: Growth in ataxia telangiectasia
}

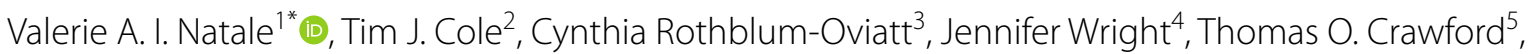 \\ Maureen A. Lefton-Greif ${ }^{6}$, Sharon A. McGrath-Morrow ${ }^{7,8}$, Haley Schlechter ${ }^{8}$ and Howard M. Lederman ${ }^{4}$
}

\section{Correction to: Orphanet J Rare Dis (2021) 16:123 https://doi.org/10.1186/s13023-021-01716- 5}

Following the publication of the original article [1] the authors became aware of an error in Fig. 7: The labels over the purple bars were unfortunately interchanged.

- 1.31 corresponds to 'Longer survival (classic)', while -2.88 corresponds to 'Early death (classic).

The correct Fig. 7 is included in this Correction and has already been updated in the original article.

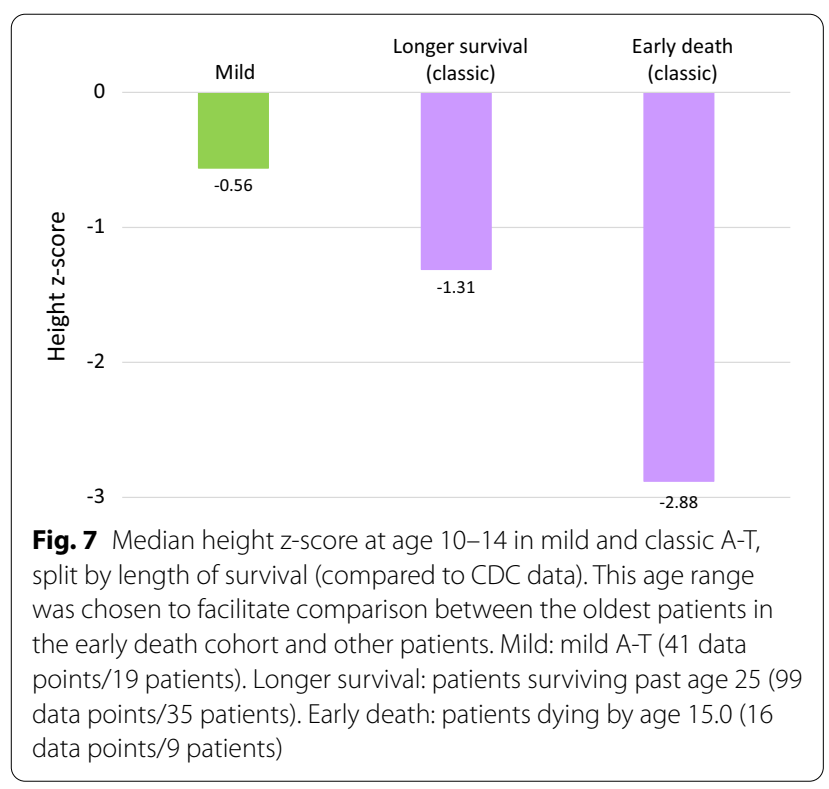

The original article can be found online at https://doi.org/10.1186/s13023021-01716-5.

*Correspondence: vnatale@forgottendiseases.org

1 Forgotten Diseases Research Foundation, Santa Clara, CA, USA

Full list of author information is available at the end of the article

\begin{abstract}
Author details
${ }^{1}$ Forgotten Diseases Research Foundation, Santa Clara, CA, USA. ${ }^{2}$ UCL Great Ormond Street Institute of Child Health, London, UK. ${ }^{3} \mathrm{~A}$-T Children's Project, Coconut Creek, FL, USA. ${ }^{4}$ Division of Pediatric Allergy and Immunology, The Johns Hopkins Medical Institutions, Baltimore, MD, USA. ${ }^{5}$ Departments of Pediatrics and Neurology, Johns Hopkins School of Medicine, Baltimore, MD, USA. ${ }^{6}$ Departments of Pediatrics, Otolaryngology-Head and Neck Surgery, and Physical Medicine and Rehabilitation, Johns Hopkins School of Medicine, Baltimore, MD, USA. ${ }^{7}$ Children's Hospital of Philadelphia Division of Pulmonary Medicine and Sleep, Philadelphia, PA, USA. ${ }^{8}$ Institute for Clinical and Transla-

Tional Research, Johns Hopkins School of Medicine, Baltimore, MD, USA.
\end{abstract}

Published online: 01 June 2021

\section{Reference \\ 1. Natale, et al. Growth in ataxia telangiectasia. Orphanet J Rare Dis. 2021;16:123. https://doi.org/10.1186/s13023-021-01716-5.}

\section{Publisher's Note}

Springer Nature remains neutral with regard to jurisdictional claims in published maps and institutional affiliations.

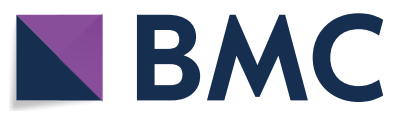

(c) The Author(s) 2021. Open Access This article is licensed under a Creative Commons Attribution 4.0 International License, which permits use, sharing, adaptation, distribution and reproduction in any medium or format, as long as you give appropriate credit to the original author(s) and the source, provide a link to the Creative Commons licence, and indicate if changes were made. The images or other third party material in this article are included in the article's Creative Commons licence, unless indicated otherwise in a credit line to the material. If material is not included in the article's Creative Commons licence and your intended use is not permitted by statutory regulation or exceeds the permitted use, you will need to obtain permission directly from the copyright holder. To view a copy of this licence, visit http://creativecommons.org/licenses/by/4.0/. The Creative Commons Public Domain Dedication waiver (http://creativeco mmons.org/publicdomain/zero/1.0/) applies to the data made available in this article, unless otherwise stated in a credit line to the data. 